DOI: 10.20472/EFC.2019.011.006

\title{
ROGNEDA GROZNYKH
}

Ural Federal University, Russian Federation

IGOR DRAPKIN

Ural Federal University, Russian Federation

OLEG MARIEV

Ural Federal University, Russian Federation

\section{DETERMINANTS OF FOREIGN DIRECT INVESTMENT INFLOWS: THE CASE OF HETEROGENEOUS RUSSIAN REGIONS}

\begin{abstract}
:
The research is devoted to analysis of various regional factors that attract foreign direct investment. Taking into account that foreign direct investment can give a possibility to solve different social and economic problems, the main objective of the study is to reveal factors that promote foreign direct investment to regions of Russia. In the research two types of regions are considered: mining and non-mining. It is proposed that mining regions in Russia attract more foreign direct investment compared to non-mining ones. Therefore we provide econometric estimation on the database for 83 Russian regions for period from 2001 to 2017 using fixed-effects regression estimation. According to the results of the research a range of recommendations can be developed in order to enlarge foreign direct investment inflows.
\end{abstract}

\section{Keywords:}

foreign direct investment inflows, Russian regions, mining region, education, roads density, railway density

JEL Classification: F21 


\section{Introduction}

The few past decades have shown that Russian economy meets serious challenges. It includes the need of economic and political systems modernization, the sharpening of international competition for resources and markets and the requirement of technologies development. One of the possible ways to overcome the mentioned problems is foreign direct investment attraction, which are considered to provide employment, to increase the efficiency of the production and economy in a whole, to lead to technological progress by technologies exchanges. That may result the improvement of households income and provide sustainable and balanced economy development and economic growth.

The attraction of foreign direct investment can be observed at three levels: national, regional and firm-level. The analysis at regional level means analyzing activities in different spheres: from production development to transport and business infrastructure and socio-cultural improvement. It combines micro- and macroeconomic factors that investors consider. Therefore, it is necessary to reveal factors influencing foreign direct investment inflows, which has both theoretical and practical value.

The specific feature of Russian economy is high interregional differentiation by basic social and economic indicators. That is why, the amount of foreign direct investment received by the regions strongly differs. The analysis provided in the article is supposed to reveal main characteristics of Russian regions that increase foreign direct investment inflows.

The creation of favorable investment climate and the solution of problems considering foreign direct investment attraction to Russian regions are highly related to variety of economic, social, political and infrastructural aspects of regional development. More precise, the socio-economic differentiation of Russian regions has to be considered. It complicates both the conduction of institutional reforms and integration of Russian regions in frames of national and global economy.

In the report of United Nations organization (2014) it is mentioned that in the Russian foreign direct investment structure prevail investment to raw materials sector. In our study we consider that there is a high correlation between gross value added (GVA) of mining operations in a certain region with the amount of foreign direct investment inflows to it.

Therefore, two types of regions are considered In the research: regions with prevailing mining production and non-mining regions. So, our main hypothesis considers that regions with higher indicators of mining manufacturing attract larger amount of foreign direct investment. The second hypothesis considers that all regional features will be more significant for regions with lower mining production.

\section{Literature review}

High differentiation in socio-economic development of Russian regions began to arouse interest by the scientists from 1990-ies, when Russian economy experienced serious transformation. For example, Brock in 1998 conducted a research on Russian regions, where concluded that gross regional product and level of crimes influence foreign direct investment inflows, which was explained by unstable political situation and transition period (Brock, 1998). 
Further research considered modernization of Russian economy. Except the size of regional economy such indicators as investment climate, infrastructure development, geographical characteristics, resource endowment and urbanization level were considered. For example, Iwasaki and Suganuma (2005) included in their analysis atmospheric temperature, natural resources endowment, industrialization and urbanization levels. The result of their study has confirmed that natural resources and market size of a region are the most significant factors. Urbanization and industrialization levels also appeared to be significant. Other determinants, for example, temperature tends to have different effect depending from the region (Iwasaki, 2005).

Later research provided evidence of impact of investor-country GDP on foreign direct investment inflows, same as agglomeration effect and labor endowment, infrastructural development and institutional factors (political risks) (Ledyaeva, 2007).

In 2016 Russian economists conducted a research in order to determine factors that influence foreign direct investment attraction to Russia applying gravity model. Gravity approach considers market size of host region (GRP) and market size of investing country (GDP) and distance between them. The main assumptions of the model is that GRP and GDP positively affect foreign direct investment inflows, while distance has negative influence. They also introduce such factor as remoteness, openness of the region and level of crimes. According to the study, all factors accept remoteness from investor positively affects FDI inflows. Distance from further Russian regions to Moscow appeared to be insignificant (Drapkin, 2016).

Similar research was provided recently for China. The authors analyze data on Chinese regions considering such determinants as country of origin, sector, wage, land price, education funding, higher education enrollment, GRP, agglomeration and intellectual property rights protection. According to authors, education, market size of region and gross regional product are the most significant determinants for European countries and USA. Such factor as sector is considered to be significant for all countries. And the results of estimations show that the amount of foreign direct investment highly differs according to sector (Belkhodja, 2016).

According to our analysis, we suggest a classification of main regional factors that can influence foreign direct investment inflows. Therefore, we consider six different groups of factors:

- economic factors (main economic features of a region: market size, price of production factors, quality of production factors). Foreign investors are interested in economic potential of a specific region. The higher level of gross regional product indicates higher regional potential and, therefore, makes it more attractive for foreign investor;

- development of regional infrastructure. The level of regional development indicates possible costs and difficulties associated with goods transportation. The development of regional transport infrastructure lightens delivery and contributes to rapid and efficient goods distribution between the customers. This indicator includes level of communication technologies development;

- regional economic policy - political situation in the region that can influence on economic activity of national and foreign agents;

- openness of the region to international relationship. The indicator of region participation level in international trade; 
- geographical features of the region. Russia is a large country and different regions have various climate conditions, access to sea. Considering Russia, this factor has more important impact, because it is connected with transaction costs. So the regions, which are situated closer to Moscow, tend to receive more foreign direct investment;

- institutional development of the region. Institutional development of the region indicates the level of property rights protection, rule of law, level of corruption etc. That is why institutions play a high role in foreign direct investment attractiveness. The region with higher institutional development is considered to attract larger amounts of foreign direct investment.

\section{Data and methodology}

To identify the effects of the range of regional characteristics on foreign direct investment inflows, we conduct the research based on the dataset on 83 Russian regions ( 3 regions were excluded from the sample because of data absence) in the period from 2001 to 2017 . The main source for regional-level data is Rosstat (Federal State Statistics Service).

The dependent variable is amount of foreign direct investment received from abroad.

According to the factors description mentioned above, the initial equation of our model can be presented as follows:

$$
\begin{gathered}
\operatorname{lnFDI} I_{i t}=\beta_{0}+\beta_{1} \operatorname{lnGRP}_{i t}+\beta_{2} \operatorname{lnHEDUC}_{i t}+\beta_{3} \ln P E D U C_{i t}+\beta_{4} \ln A V W A G E_{i t}+\beta_{5} U N E M P_{i t} \\
\beta_{6} \ln \text { AUTOROAD }_{i t}+\beta_{7} \ln R A I L_{i t}+\beta_{8} T R A D E_{i t}+\beta_{9} A D M I N_{i t}+\beta_{11} \operatorname{lnCRIME_{it}}+\varepsilon,
\end{gathered}
$$

where the dependent variable is $\ln F D I_{i t^{-}}$logarithm of total amount of foreign direct investment (thousand dollars). As explanatory variables we include: $\ln G R P_{i t^{-}}$logarithm of gross regional product per person (rub), $\ln H E D U C_{i t}$ - logarithm of yearly average volume of people with higher education employed, $\ln P E D U C$ - logarithm of yearly average volume of people with secondary education employed, $\ln A V W A G E_{i t^{-}}$logarithm of yearly average nominal wage (rub), UNEMP ${ }_{i t^{-}}$ level of unemployment (\%), $\ln A U T O R O A D_{i t}$ - density of roads at the yearend $(\mathrm{km} / 1000 \mathrm{~km} 2)$, InRAIL $L_{i t^{-}}$density of railways at the yearend $(\mathrm{km} / 1000 \mathrm{~km} 2), T R A D E_{i t}$ - openness of region calculated as ratio of sum of export and import to GRP, $A D M I N_{i t}$ - level of citizens satisfaction of

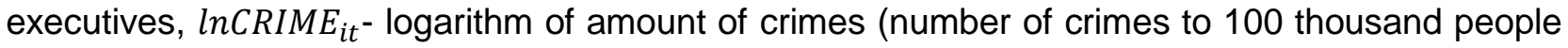
ratio).

The main methods for estimating the present model (considering that our database is panel data) are regression with fixed effects and random effects. After estimating both models we conduct Hausman test to choose between fixed-effects estimation and random-effects estimation. According to the test, the null hypothesis considers no systematic difference in coefficients. If the null hypothesis is not rejected than the random effect regression is more preferred.

In addition we run two regressions for different type of region: non-mining and mining regions. The regions are divided into two groups by the share of mining in gross value added structure by region. So, 11 mining regions were revealed. All other regions consider to be non-mining.

The analysis is supposed to test two main hypothesis: mining regions receive more foreign direct investment compared to non-mining ones and regional factors are more significant for non-mining regions. 
We consider that all factors have to affect positively foreign direct investment inflows except number of crimes. This indicator has to have negative effect on attraction of foreign direct investment, and, as we suggest, the influence might be more significant for non-mining regions.

\section{Results of empirical analysis}

For our research we have first tested the general econometric model for the whole list of regions. By the Hausman test it is confirmed that fixed-effects model is more sufficient due to rejected null hypothesis.

As the next step we divide all regions by share of mining production in gross value added. And run two regressions for mining and non-mining regions. The results are displayed in the table 1.

Table 1: Results of basic econometric regression for mining and non-mining Russian regions

\begin{tabular}{|c|c|c|}
\hline Explanatory variables & $\begin{array}{l}\text { Panel data with fixed effects } \\
\text { (mining regions) }\end{array}$ & $\begin{array}{l}\text { Panel data with fixed effects } \\
\text { (non-mining regions) }\end{array}$ \\
\hline Logarithm of gross regional product & $0.973^{\star \star \star}$ & 0.124 \\
\hline $\begin{array}{l}\text { Logarithm of yearly average volume } \\
\text { of people with higher education } \\
\text { employed }\end{array}$ & 0.581 & $0.062^{*}$ \\
\hline $\begin{array}{l}\text { Logarithm of yearly average volume } \\
\text { of people with secondary education } \\
\text { employed }\end{array}$ & $0.885^{*}$ & $0.066^{*}$ \\
\hline $\begin{array}{l}\text { Logarithm of yearly average nominal } \\
\text { wage }\end{array}$ & $0.782^{\star \star \star}$ & $0.893^{\star \star \star}$ \\
\hline Unemployment level & $0.799^{*}$ & $0.742^{\star \star}$ \\
\hline Density of roads & $0.459^{\star \star}$ & $0.573^{\star \star \star}$ \\
\hline Density of railways & $0.573^{\star \star}$ & $0.314^{\star \star}$ \\
\hline Openness & $1.249^{\star \star \star}$ & $0.921^{\star \star \star}$ \\
\hline $\begin{array}{l}\text { Level of citizens satisfaction of } \\
\text { executives }\end{array}$ & 0.809 & $0.041^{* *}$ \\
\hline Logarithm of number of crimes & $-0.732^{*}$ & $-0.391^{\star \star}$ \\
\hline Number of observations & 187 & 1224 \\
\hline R-squared within & 0.6119 & 0.6757 \\
\hline R-squared between & 0.4348 & 0.5797 \\
\hline R-squared overall & 0.4514 & 0.5852 \\
\hline
\end{tabular}


In the result of our estimation two our hypothesis were confirmed: mining regions attract more foreign direct investment and regional characteristics are more significant for non-mining ones (in some cases).

Aligning with gross regional product investors consider manufacturing development in the region. However, this factor is significant only for mining regions, which can be explained that investor is seeking for a higher output of his investment. For the non-mining regions gross regional product appeared to be insignificant.

Level of education (both higher and secondary) has positive influence on foreign direct investment attraction, but its significance is not very high, which was unpredicted. According to the previous research, education usually more significant in developed countries (Belkhodja, 2016). The effect of secondary education is stronger for mining regions, because such labor force is demanded in manufacturing field and most of foreign direct investment that flow into Russian economy, are flowing to mining sector. Higher educated workers are still needed, but the amount of them is much less comparing to secondary educated workers.

Average nominal wage appeared to have positive and significant impact. This can be explained by increasing incomes that might lead to potential enlargement of customers demand on the produced goods.

Unemployment level have positive impact on foreign direct investment attraction, but significant only at $10 \%$ significance level. What is more significant, according to the results, is density of auto roads and railways. Improvement of the factor can increase FDI inflows to certain regions due to infrastructure development and transportation costs decrease.

As institutional factors we have included level of citizens satisfaction of executives and number of crimes. These two indicators do not have any strong significance. It can be explained by the fact that investor, first of all seek for the sector (for example, mining region), then other factors tend to be not so significant. For our future research we suppose that including "property rights protection" as institutional factor would be at high signigficance level both for mining and nonmining regions.

\section{Conclusion}

According to previous research a system of factors that influence foreign direct investment attraction to Russian regions was developed. We consider 6 groups of factors that are included in our regression. In a whole, amount of FDI tends to highly correlate with a more developed economic sector in a region. Our analysis has revealed that in a whole such factors as size of market (gross regional product), average wage, openness and infrastructure development are the most significant indicator both for mining and non-mining regions. Still, additional factors are more important for non-mining regions. We explain such result by the fact that some of Russian region are more endowed with natural resources, which are a object of interest of foreign investors. To improve the situation, other regions have to develop infrastructure, increase educational level of citizens and improve institutional policy in order to attract more FDI for further development. 


\section{Acknowledgements}

This research was supported by the President of Russia grant "Institutional determinants of foreign direct investment inflows: country and region level analysis" (grant No. MD 6402.2018.6).

\section{References}

BELKHODJA, O., MOHIUDDIN, M., KARURANGA, E. (2016): The determinants of FDI location choice in China: a discrete-choice analysis. Applied Economics. 49 (13). P. 1241-1254.

BEVAN, A., ESTRIN, S. (2004). The determinants of foreign direct investment into European transition economics. Journal of Comparative Economics. 32. P. 775-787.

BLONINGEN, B. A., DAVIES, R. B., WADDELL, G. R., NAUGHTON, H. T. (2007): "FDI in space: Spatial autoregressive relationships in foreign direct investment". European Economic Review. Vol. 51. P. 1303-1325.

BROCK, G. (1998): Foreign Direct Investment in Russia's Regions 1993-95. Why So Little and Where Has it Gone? Economics of Transition. Vol. 4. P. 349-360.

IWASAKI I., SUGANUMA K. (2005): Regional Distribution of Foreign Direct Investment in Russia. PostCommunist Economies. Vol. 17. P. 153- 172.

KARIMI, M., YUSOP, Z., HOOK, L., CHIN, L. (2013): Effect of Human Capital on Foreign Direct Investment Inflows. Journal of Economic Research. 18. P. 1-23.

LEDYAEVA, S. (2009). Spatial Econometric Analysis of Foreign Direct Investment Determinants in Russian Regions. The World Economy. P. 1- 38.

MARIEV, O., DRAPKIN, I., CHUKAVINA, K., RACHINGER, H. (2016): Determinants of FDI inflows: The case of Russian regions. Economy of Region. Vol. 12 (4). P. 1244-1252.

TOCAR, S. (2018): Determinants of Foreign Direct Investment: A Review, Review of Economic and Business Studies. Vol. 11(1). P. 165-196.

ROSSTAT [URL: http://www.gks.ru/wps/wcm/connect/rosstat_main/rosstat/ru/statistics/accounts/]

WANG, M. (2011): FDI and human capital in the USA: is FDI in different industries created equal? Applied Economic Letters. 18 (2). P. 163-166

WORLD INVESTMENT REPORT (2014): Investing in the SDGs: An action plan, United Nations Conference on Trade and Development, [URL:https://unctad.org/en/PublicationsLibrary/wir2014_en.pdf] 